\title{
The Relationship between Language Learners' Anxiety and Learning Strategy in the CLT Classrooms
}

\author{
Kun-huei Wu \\ Department of English, Aletheia University \\ 32 Chen-Li St., Tamsui, Taipei, Taiwan \\ Tel: 886-2-26212121 ext.1142Ｅ-mail: au4284@mail.au.edu.tw
}

\begin{abstract}
This paper intends to explore how Taiwanese students perceive the relationship between their language learning strategy and anxiety in the foreign language classroom. Due to their previous learning experience, most of the participants hold an unfavorable attitude toward a grammar-translation teaching approach. Consequently, learner-centered instruction has been widely accepted and acknowledged as a welcome concept and feasible teaching approach in the English Foreign Language (EFL) context. To improve the proficiency of language learners in EFL classrooms, it is very important to take into account the need of the learners. The present study utilizes Foreign Language Classroom Anxiety Scale (FLCAS) and Communicative Language Teaching Attitude Scale (COLTAS) to examine the participants' perceptions about learning English. The results indicate that most of the participants express a favorable attitude toward the Communicative Language Teaching (CLT) approach; however, they also reveal their high level of anxiety in the language classroom. Language anxiety is usually reported to have adverse effects on the learning of a second language. It is the language instructors' mission to accelerate the language learning of their students. One way is to teach students how to learn more effectively and efficiently. Language learning strategies (LLS) are procedures that learners can use to facilitate learning. Both teachers and students should develop an awareness of the learning process and strategies that lead to success. The ultimate goal of this paper is to analyze the factors that affect the participants' learning strategies and their language anxiety, and offer some pedagogical suggestions.
\end{abstract}

Keywords: Communicative Language Teaching, COLTAS, Anxiety, FLCAS, LLS

\section{Introduction}

Language learning/teaching entails five major components—students, teachers, teaching approaches, teaching materials, and evaluation. Conventionally, the instructor in the teacher-centered model determines what the teaching materials will be and tries to transmit them in one way or another. The test of learning is dependent heavily on the students' ability to memorize and produce the data at stated intervals. In this case, the students' task is to listen, remember, and then give evidence that they have registered the materials in their minds. Students, in the EFL context, focus on memorizing vocabulary, phrases, grammatical rules, and sentence structure, but they have difficulties applying the target language to their real life. The teacher-centered model in language classrooms has been questioned in educational circles. One way to modify this traditional pattern of teaching/learning is to give students more responsibility for learning. Some educators have maintained that the teacher at best can only establish an atmosphere for learning; the student must learn as a result of individual efforts (Webb, C. and Baird H., 1968). The concept of a student-centered approach has been acknowledged and accepted as one of the most feasible educational methodologies (Copeland, 1952). Teachers need to encourage students to rely more on themselves and less on the teacher. Students should be self-motivated with an inquiring nature. A number of studies reveal that motivation and attitude are closely related to achievement in language learning (Gardner and Lambert, 1972). Gardner (1985) defines motivation as "the combination of effort, desire to achieve the goal of learning the language, and favorable attitudes toward learning the language."

There are various factors affecting the learning of a foreign language, such as intelligence, motivation, attitude, age, gender, personality, anxiety, and so on (Skehan,1989). Language acquisition should be achieved naturally; however, learning a foreign language in the classroom, for most students, is full of challenges. One of the known challenges comes from the learners' affective factor, i.e., anxiety. Horwitz et al. (1986) define foreign language anxiety as "a distinct complex of self-perceptions, beliefs, feelings, and behaviors related to classroom language learning arising from the uniqueness of the language learning process" (p.128). A plethora of studies on the relationship between language learning and anxiety (Aida, 1994; Brown, 2000; Cheng, 2002; Ewald, 2007; Horwitz et. al., 1986; Young, 1992). Saito \& Samimy (1996) assert that anxiety has a significant impact on language learning and achievement. Some studies conclude that high levels of anxiety usually have a negative effect on the language acquisition process (Gregersen, T., 2003; Krashen, 1985b; MacIntyre and Gardner, 1991; Price, 1991).

Language learners find it difficult to immerse themselves in an unfamiliar language setting. In this case, the target 
language should be taught through mixed approaches designed for specific purposes. In the 1950s and 1960s, the grammar-translation and audio-lingual method of language teaching prevailed; however, the premium put on spoken communicative competence attracted more and more attention in the 1970s. Since then, the communicative approach has become one of the preferable choices in English language teaching. It is generally believed that language learning can be most effective when language practice occurs in meaningful contexts instead of isolated linguistic settings. Communicative Language Teaching (CLT), a teaching innovation that has spread widely over the past two decades, is arguably the most popular teaching method in the field of English Language Teaching (ELT). Beginning in the 1970s, voices for improving students' communicative competence became louder; the necessity to adopt another practical teaching method emerged. Communicative Language Teaching (CLT) is one of the methods featured in developing learners' communicative competence (Hymes, 1972). From its introduction into the discussion of language and language learning, the term "communicative competence" has prompted reflection. Although it is extensively practiced in English as a Second Language (ESL) setting, it is not clear whether CLT is also being applied in the English as a Foreign Language (EFL) setting.

The present paper intends to explore learners' anxiety vis-à-vis the student-centered model in the CLT context. The major setting is a learning/teaching environment where language learners shift from passive to active roles. In other words, the focus will be altered from a traditional teacher-centered approach to a learner-centered one. The ultimate aim of this study is to examine the reliability and feasibility of the learner-centered model, and the variables that affect language performance in the EFL classroom.

\section{Related Study on Anxiety}

Tallon (2009) indicates that many factors determine the outcome of the learning process, including individual differences such as cognitive abilities, personality characteristics, learning styles, meta-cognitive differences, social contexts, and affective aspects. He points out that one of the most important affective variables in learning a foreign language is foreign language anxiety. The effects of anxiety on foreign language learning have been extensively reported in social psychology, educational psychology, and speech communication. Nevertheless, the issue of whether anxiety is a stable construct was questioned until the Foreign Language Classroom Anxiety Scale (FLCAS) (See Appendix A). Horwitz et al. (1986) isolated foreign language anxiety from other forms of anxiety and provided a reliable and valid measure to gauge university students' level of anxiety. Language anxiety is the feeling of tension and apprehension specifically in second-language contexts, including speaking, listening, reading, and writing (MacIntyre and Gardner, 1994). It has been estimated that approximately one-third of students learning a foreign language experience some type of foreign language anxiety (Horwitz et al., 1986). Elkhafaifi (2005) makes a study concerning listening comprehension and anxiety in the Arabic language classroom. Phillips (1992) focuses on the effects of language anxiety on students' oral test performance and attitude. Sellers (2000) presents the relationship between reading and anxiety in Spanish as a foreign language. Cheng (2002) analyzes factors associated with foreign language writing anxiety in the EFL context. Students or language learners in these studies experience different levels of anxiety.

Crookall and Oxford (1991) assert that serious language anxiety may adversely affect students' self-esteem, self-confidence, and ultimately hamper proficiency in language acquisition. Typically, there are three types of anxiety: trait, state, and situation-specific (Spielberger, 1966). Trait anxiety is a relatively stable personality characteristic in a wide range of situations. A person with this predisposition tends to become predictably nervous in any situation (Spielberger, 1983). State anxiety refers to the transient emotional state of feeling nervous that can fluctuate over time and vary in intensity, i.e., a moment-to-moment experience of anxiety (Goldberg, 1993). Situation-specific anxiety is like trait anxiety, but it refers to apprehension in a particular context or situation, such as math anxiety, stage fright, or fear of public speaking. Generally speaking, foreign language anxiety is seen as related to situation-specific anxiety. Most scholars agree that foreign language anxiety is a complex phenomenon and predicator of foreign language achievement.

\subsection{Anxiety-provoking sources and impact on L2 learning}

Horwitz et al. (1986) identify three related foreign language anxieties: communication apprehension, test anxiety, and fear of negative evaluation. Communication apprehension refers to the fear of communicating with other people. It is a type of shyness characterized by fear or anxiety about communicating with people. Test anxiety is about the fear of exams, quizzes, and other assignments used to evaluate students' performance. The fear of negative evaluation refers to the apprehension about others' evaluation. Young (1994) categorizes anxiety-provoking sources into three groups: learner-related, instructor-related, and instructional practice-related. There are numerous anxiety-provoking sources in the classroom, such as speaking activities, negative classroom experience, native speakers, a harsh teaching manner, inability to comprehend, the learner' learning style, and the learning context (Oxford, 1999; Phillips, 1999; Reid, 1995; Samimy,1994). Young (1999) points out that speaking or giving a presentation in front of the class is an in-class activity producing high level of anxiety.

Although studies reveal that anxiety may result in adverse effects on language learning, it is also believed that anxiety 
could motivate language learning. Alpert and Haber (1960) distinguish harmful and helpful anxiety as facilitative and debilitative anxiety. Facilitative anxiety is seen as a drive to improve performance. Debilitative anxiety, on the contrary, hinders a learner's achievement. A number of studies have shown that language anxiety brings forth potential negative effects on academic achievement, such as communication skills, oral proficiency, reading comprehension, listening skills, and writing skills. Most of the studies reveal that high-anxious learners either expect or receive lower grades than their less anxious peers. It is important for teachers and educators to create a less threatening environment in which language learners may learn more efficiently. Those who have higher levels of anxiety are likely to be reticent or unwilling to communicate in the classroom. Ellis (1994) indicates that anxiety is one of the main reasons for learners' reticence.

\subsection{Reticence in the Classroom}

Kachru (1997) presents his concentric circle model to analyze the spread and diffusion of English. Asian countries such as Taiwan, Japan, Korea, and China have been categorized in the expanding circle where English is primarily a foreign language. As English is increasingly becoming the "lingua franca," the above-mentioned countries have undertaken reform in the teaching of English as a foreign language. However, students from the countries mentioned are reticent and passive learners (Cortazzi and Jin, 1996; Flowerdew and Miller, 1995; Jones, 1999; Li, 1998; Tsui, 1996). They are often reluctant to participate in classroom discourse. Studies also reveal that many are unwilling to give response, seldom ask questions, and are overly dependent on the teacher.

One of the contributing factors to this phenomenon is traditional culture. Confucian influences are regarded as the main cause of perceived reticence in students from Asian countries. In other words, teachers dominate the learning process, while students passively receive the knowledge from the teachers. Culture and previous education are cited as plausible factors shaping students' apparent reticent behavior. Kubota (1999) indicates that Asian culture generally value collectivism and discourage individual self-expression. Nimmannit (1998) points out that Chinese student self-image and identity are dependent on their relationship with classmates; as a result, they may feel uncomfortable when asked to answer questions or express ideas. Turner and Hiraga (1996) indicate that Japanese students in Britain appear passive and unwilling to engage in dialectic and analytic discourse in tutorials; and they attribute such passive behavior to Japanese academic culture, which values the demonstration rather than transformation of knowledge. In their study, Littlewood and Liu (1997) address some of the reasons for student reticence, such as a lack of experience, lack of confidence, anxiety due to high performance expectations, and their perception of the learner role.

In the EFL context, one of the striking reasons for learner reticence is due to lack of experience in speaking English. Kouraogo (1993) attributes learner reticence to environment in which most L2 learners communicate in L1 outside the classroom. Students in such an environment lack confidence in their spoken English and become anxious when they need to use English as a vehicle of communication. In a teacher-centered teaching model, the teacher does all the lecturing in the classroom. Typical learning strategies such as reception, memorization and reproduction, and mastery seem to encourage learners to be more passive. Much attention is paid to language form instead of its function. It is not surprising that the majority of the language learners are capable of learning to read the target language with varying degrees of success, but when it comes to oral communication, most of them become hopelessly dysfunctional (Huang, 1990).

\section{Study on attitude toward CLT}

CLT is arguably today's most popular teaching method in the field of English Language Teaching (ELT). Although it is extensively practiced in the English as a Second Language (ESL) setting, it is not clear CLT is also being applied in the English as a Foreign Language (EFL). Savignon (1991) indicates that CLT is not a British, European, or U.S. phenomenon, but rather an international effort to respond to the needs of the contemporary classroom (p.261).

Nevertheless, it is difficult to define CLT due to the complexity and interrelatedness of skills in both written and oral communication. For the sake of simplicity and directness, Brown (2001) lists six interconnected characteristics of CLT. First, classroom goals are focused on all of the components (grammar, discourse, function, sociolinguistic characteristics, and strategies) of communicative competence. Goals must intertwine with the organizational and pragmatic aspects of language. Second, language techniques are designed to engage learners in the pragmatic, authentic, functional use of language for meaningful purposes. Organizational language forms are not the focus, but rather aspects of language that enable the learner to accomplish those purposes. Third, fluency and accuracy are seen as complementary principles underlying communicative techniques. At times, fluency may have to take on more importance than accuracy in order to keep learners meaningfully engaged in language use. Fourth, students in a communicative class ultimately have to use the language, productively and receptively, in unrehearsed contexts outside the classroom. Classroom tasks must therefore equip students with the skills necessary for communication in those contexts. Fifth, students are given opportunities to focus on their own learning process through an understanding of their own styles of learning and through the development of appropriate strategies for autonomous learning. Sixth, the role of the teacher is that of facilitator and guide, not an all-knowing bestower of knowledge. Students are therefore encouraged 
to construct meaning through genuine linguistic interaction with others (p. 43).

In the teacher-centered model, the grammar-translation approach has made language learners become more passive and reticent. And the shortcomings of audio-lingual methodology are widely acknowledged (Savignon, 1991). It is necessary, therefore, for teachers to adopt another teaching approach that better suits the needs of language learners. From its introduction into discussions of language learning, the term "communicative competence" has prompted reflection. English teachers from countries such as China, Greece, South Korea, and Turkey have made attempts to implement CLT; however, research has shown that English teachers from these countries have faced many constraints that have hindered them from fully adopting this approach (Burnaby and Sun, 1989; Eveyik-Aydin, 2003; Karavas-Doukas, 1996; Li, 1998). Some of the more common constraints include large classes, grammar-based examinations, teachers' lack of cultural knowledge, lack of communicative teaching materials, and students' low English proficiency. The aforementioned studies affirm the importance of understanding and taking into account teacher and student attitudes toward innovative teaching (CLT) and abilities when attempting such an approach. As Li (1998) points out, "How teachers as the end users of an innovation perceive its feasibility is a crucial factor in the ultimate success or failure of that innovation" (p. 698). Karavas-Doukas (1996) examines Greek English teacher attitudes toward CLT and finds that most have mildly favorable to favorable opinions of this methodology. Nevertheless, upon observing some of these teachers in the classroom, researchers find that teaching practices do not correspond with attitudes toward CLT. There is an emphasis on form, the classes are teacher-centered, and there are no group activities. In this case, the discrepancy is caused by a lack of understanding of CLT principles. The author makes note of the importance of not discounting teachers' beliefs and attitudes prior to the introduction of a new teaching method.

Eveyik-Aydin's (2003) examination of Turkish English teacher attitudes toward CLT indicates that most have a favorable attitude with some reservations. These reservations concern constraints that are caused by the educational system-large classes and inflexible curriculum; teachers' beliefs and educational values; and the student's low proficiency, fear of making mistakes, and the pressure of having to pass national examinations. In their study on the effect of language context on Chinese teachers' views of CLT, Burnaby and Sun (1989) find that teachers perceive the communicative approach as more suitable for those planning to study or live in an English speaking country (English as a Second Language (ESL) context), but not for those, especially English majors, who plan to remain in China (English as a Foreign Language (EFL) context). For the latter, the traditional methods are perceived to be more appropriate, given their specific needs and learning goals. The study also reveals that local teachers view their non-native English speaking teacher status as a limitation (e.g., lack of familiarity with authentic texts, lack of knowledge in regards to appropriate cultural contexts, and no target language "intuition"). Furthermore, the pressure to teach to grammar-focused examinations, the clash of teaching philosophies, large classes, and a lack of resources are all seen as constraints on the application of CLT.

Li's (1998) study of South Korean English teacher's perceived difficulties in adopting CLT is similar to the above. Perceived difficulties specifically related to teachers include teacher deficiency in spoken English and strategic and sociolinguistic competence, lack of training in CLT, limited opportunities for retraining in CLT, misconceptions about the approach, as well as a lack of time and expertise to develop communicative materials. Perceived educational system constraints consist of large classes, grammar-based examinations, and lack of funding and support. Perceived difficulties caused by CLT itself include an inadequate account of EFL teaching and a lack of effective and efficient instruments for assessment. Finally, perceived difficulties related to students included low English proficiency, little motivation for communicative competence, and resistance to class participation. This last point is further endorsed by two studies investigating student attitudes toward CLT. In Matsuura, Chiba, and Hilderbrandt's (2001) study, Japanese students prefer traditional methods-learning isolated skills, focusing on accuracy, and the teacher-centered approach. The Chinese students in Rao's (2002) study prefer non-communicative activities such as audio-lingual drills and workbook type drills over communicative activities.

The current communicative approaches to second language instruction emphasize the importance of learners using the L2 in oral and written tasks. However, language learners in the EFL context are usually reported reticent and passive. It is important to understand their problems and provide appropriate learning strategies to help them learn more effectively and efficiently. A learner's willingness to communicate is related to a variety of factors such as motivation, attitude, English proficiency, foreign language anxiety, situational context, language learning strategy and so forth. (Yashima et al., 2004). This paper will attempt to conduct an investigation of the select participant attitudes toward CLT, examining factors resulting in their language anxiety, discussing the impact of their language learning strategies on their performance in the CLT classroom, and thus provide some pedagogical suggestions for the instruction of English.

\section{The Study}

The concept of the student-centered approach is no longer new in educational circles. English education in Taiwan has recently shifted from grammar-focused reading methods to more communication-oriented ones. However, it is not easy to implement fully the student-centered approach. Horwitz et al. (1986) note that one-third of students learning a foreign 
language experience some type of foreign language anxiety. Why do many students appear unwilling to participate in the learning discourse? MacIntyre et al. (1998) define willingness to communicate (WTC) as a learner's "readiness to enter into discourse at a particular time with a specific person or persons, using a L2." Yashima and Zenuk-Nishide (2004) reveal that a learner's WTC influences how frequently the learner actively engages in communicating in the L2. Asian learners from Japan, Hong Kong, Taiwan, China, and South Korea are reported passive and unwilling to participate and communicate in the classroom. Early models of WTC predict that high levels of perceived competence combined with low levels of anxiety would lead to greater WTC and in turn more frequent communication in the L2. Studies (Flowerdew, J. and Miller, L., 1995; Ferris, D. and Tagg, T., 1996) reveal culture and previous education are the main reasons for student reticence and passivity. Cortazzi and Jin (1996) claim that learning a language for Chinese students is influenced by traditional Confucianism and can be seen as fundamentally concerned with mastery of grammar and vocabulary. The students obtain their knowledge mainly from two authoritative sources: the teacher and the textbook. The role of a teacher is to transmit the knowledge about language to students in the language classroom. Students receive the instruction from their instructors with respect. The interaction between the teachers and students in the classroom is profoundly influenced by the traditional teaching/learning model.

These generalizations do not mean that all individuals, either instructor or learners, will conform to the same cultural norms. Tudor (1998) claims that language learning/teaching is unique to each classroom and difficult to predict. The traditional culture of learning has been changing partly because of social and economic developments and partly due to new communicative approaches to language learning. Thus, more and more attention is paid to student needs as a learner-centered notion. CLT emphasizes the importance of classroom interaction and student participation as ways of learning and developing skills related to the functions and uses of language. In a traditional teacher-centered teaching and learning environment, the learners are bound to be reticent and passive. With a more innovative method, the classes are likely to be completely different. In order to capture select student perception of their learning in a communication-oriented classroom, the following research questions are proposed:

(1) What are the select learner attitudes toward Communicative Language Teaching (CLT)?

(2) What is the relationship between learner anxiety and learning strategy?

(3) What are the perceived difficulties of adopting CLT in the EFL classrooms?

\subsection{Research Instrument}

The present study uses three instruments: the Communicative Language Teaching Attitude Scale (COLTAS) (Appendix A), Foreign Language Classroom Anxiety Scale (FLCAS) (Appendix B), and Strategy Inventory of Language Learning (SILL) (Appendix C). COLTAS is utilized to understand select participant attitudes and perceptions toward the four domains of CLT. FLCAS is used to examine participants' level of anxiety in the language classroom. Strategy Inventory of Language Learning will assess the participants' language learning strategy.

The Communicative Language Teaching Attitude Scale (COLTAS) developed by Eveyik-Aydin (2003) is a five-point, Likert type attitude scale consisting of 36 statements based on the fundamental characteristics of CLT and categorized into four domains: group/pair work, place of grammar, student/teacher roles, and peer/teacher corrections. Of all the statements, half of them have been designated as "negative" because they support the traditional approach to language teaching, while the other half have been designated as "positive" because they reflect the principles of CLT. As in Eveyik-Aydin's (2003) study, the positive items on the scale that reflect the principles of CLT are assigned a high score of 5 for "strongly agree" down to a low score of 1 for "strongly disagree." The negative items on the scale, those that reflect a traditional view of language teaching, are assigned a reverse score of 1 for "strongly agree" up to 5 for "strongly disagree." Thus, participants in favor of the communicative approach will score between 4 and 5 , whereas those in favor of the traditional approach will score between 1 and 2. Accordingly, the higher the scores obtained on COLTAS, the more favorable the participants' attitudes toward CLT; and the lower the score, the less favorable are the participants' attitudes. Scores for each participant are calculated and placed within the following categories. Scores between 180 and $144(36 \times 4)$ reveal a very favorable attitude toward CLT; whereas scores between 36 and 72 (36x2) reveal a very unfavorable attitude. A score of $108(36 \times 3)$ reveals a neutral attitude toward CLT. Scores between 109 and 143 show a favorable attitude with some reservations toward CLT, while scores between 73 and 107 reflect unfavorable attitudes with some reservations. These scores are also tabulated to determine participants' attitudes toward each of the four domains of the scale-group/pair work, grammar, student/teacher roles, and peer/teacher corrections.

The FLCAS was developed by Horwitz et al. (1986) to measure anxiety specific to a foreign language classroom setting. The scale utilizes five-point Likert items, ranging from "strongly disagree" to "strongly agree." It is used to measure a person's level of anxiety and score by adding up the ratings on the 33 items. The range is from 33 to 165; the higher the number, the higher the level of foreign language anxiety.

Learning strategies are "procedures or techniques that learners can use to facilitate a learning task" (Chamot, Barnhardtd, El-Dinary, and Robbins, 1999, p.2). Language learners become more motivated as they begin to understand 
the relationship between their use of strategies and success in learning language. Strategy Inventory of Language Learning (SILL), developed by Oxford (1989), is a 50-item, Likert-scale, self-report instrument intended to assess how frequently language learners use a variety of language learning strategies. Memory strategies, cognitive strategies, compensation strategies, meta-cognitive strategies, affective strategies, and social strategies are six main categories in SILL. Memory strategies help learners to retrieve and store information; cognitive strategies are used for forming and revising internal mental models and receiving and producing messages in the target language; compensation strategies allow learners to overcome gaps in knowledge of the language; meta-cognitive strategies help learners to self-direct language learning; affective strategies enable learners to control feelings, motivations, and lower their language anxiety; social strategies facilitate interaction with others. The modified questionnaire was designed specifically for the present study, consisting of 18 items, using a 5-point Likert scale from 1 (never or almost never true of me), 2 (usually not true of me), 3 (sometimes true of me), 4 (usually true of me) to 5 (always or almost true of me) (Appendix C). The higher the score they obtained, the more frequently the strategy is used.

\subsection{Participants}

The selected participants in the present study consist of 66 students in the weekend classes program at one of the universities in northern Taiwan. All the participants are English majors; 32 are freshmen, and 34 sophomores. They are full-time workers in various occupations; 41 are female and 25 male, aged from 23 to 54 . They come to class on the weekend, Saturday and Sunday, 9:05 a.m. to 5:00 p.m. They need to spend two years to complete the required courses, and then they graduate with a B.A. The reasons they choose English as their major are multidimensional; one of their common expectations is to improve English ability. Two native English speaking teachers are invited in this study, whose teaching experience has been over ten years. Both of them are teaching oral conversation and reading classes.

\subsection{Data Collected and Analysis}

In March 2009, a background questionnaire and a proficiency test were administered to the students. The items in the questionnaire consist of gender, age, employment status, years of learning English, and time studying English outside the classroom (Table 1). The background questionnaire is an indispensable source of information vis-à-vis their language-learning strategies and language anxiety. The proficiency test consists of 100 questions, 50 questions address reading comprehension and the other 50 listening comprehension. Based on the result of the proficiency test, they are divided into two experimental groups. The students in Group $1(n=33)$ are reported as learners with higher English proficiency, and Group $2(\mathrm{n}=33)$ lower proficiency.

\section{Insert Table 1 about here}

COLTAS was also administered to the students, 66 valid questionnaire samples were collected. The results show that 16 students had a very favorable attitude, 41 a favorable attitude with some reservation, 6 expressed uncertainty, and 3 expressed an unfavorable attitude with some reservation (Table 2). Table 2 provides a clear picture regarding student attitudes toward CLT. Overall, $24 \%$ of participants had a very favorable attitude, $62 \%$ a favorable attitude with some reservations, and $14 \%$ an uncertain attitude with some reservation.

\section{Insert Table 2 about here}

The four domains, consisting of 36 items, in CLT are teacher/student role, pair/group work, grammar, and peer/teacher correction. Of all the statements, half were "negative" because they support the traditional perspective on language teaching, while the other half were "positive" because they reflect the principles of CLT (Table 3). Table 3 itemizes participant response vis-à-vis the positive principles of CLT.

\section{Insert Table 3 about here}

According to Table 3, most of the participants have a favorable attitude toward the principles of CLT. As to student/teacher roles, the statistical analysis shows that the majority of them agree that language classes should be student-centered, not teacher-centered (item 1, $\mathrm{M}=4.21, \mathrm{SD}=0.98$ ), allowing for more student-student interaction than teacher-student interaction (item $31, \mathrm{M}=3.76, \mathrm{SD}=1.09$ ). They affirm that tasks and activities should be designed based on student needs (item 18, M=4.09, $\mathrm{SD}=1.01$ ), and that teachers should help students develop sociolinguistic competence (item 27, $\mathrm{M}=3.98, \mathrm{SD}=1.03$ ).

Regarding group /pair work, most of the participants agree that it is effective in developing student oral conversational skills (item $6, \mathrm{M}=4.01, \mathrm{SD}=1.05$ ) because it creates a motivating environment for students to use English (item 7, $\mathrm{M}=3.79, \mathrm{SD}=1.04$ ), promotes a greater amount of student involvement (item $15, \mathrm{M}=4.02, \mathrm{SD}=0.09$ ), and increases the quantity of oral/aural language practice (item $34, \mathrm{M}=3.96, \mathrm{SD}=1.02$ ). Moreover, group/pair work helps those students not willing to speak in front of a full classroom (item 16, $\mathrm{M}=3.95, \mathrm{SD}=1.01$ ).

Regarding grammar, most agree that in order to develop communicative skills, explicit grammar teaching is not necessary (item 13, $\mathrm{M}=3.78, \mathrm{SD}=1.04$ ); though grammar may be included in a communicative lesson, it is not the main goal of teaching (item $33, \mathrm{M}=3.98, \mathrm{SD}=1.12$ ). In addition, most agree that teaching should emphasize language use 
rather than language rules (item $14, \mathrm{M}=3.99, \mathrm{SD}=1.05$ ) and meaning-focused activities rather than form-focused activities (item 22, $\mathrm{M}=3.67, \mathrm{SD}=1.02$ ).

Finally, concerning peer/teacher correction, most agree that teacher correction should be avoided when it interrupts the flow of communication (item 3, M=3.31, SD=1.02); however, it ought to be provided when required for effective communication (item $25, \mathrm{M}=3.19, \mathrm{SD}=1.17$ ). They agree that feedback should focus on the content of the activities (item 10, M=3.87, $\mathrm{SD}=1.06$ ) and the appropriateness of student responses rather than on the form of the language (item 20, $\mathrm{M}=3.54, \mathrm{SD}=1.09$ ). Furthermore, most favor allowing student-student correction to take place in the classroom (item 8, M=3.27, $\mathrm{SD}=1.15$ ).

The results above reveal the select participant attitudes regarding this innovative teaching approach. Most had positive attitudes toward the four domains of CLT, although some expressed a degree of reservation. In addition to understanding participant attitudes, it is also important to gauge their levels of language anxiety in the classroom. Furthermore, it is helpful for students to develop an awareness of the learning process and strategies that lead to success in learning a second language. To achieve this goal, the Foreign Language Classroom Anxiety Scale (FLCAS) and Strategy Inventory Learning Language (SILL) were administered to the participants in April 2009 survey.

The results (Table 4) reveal that the majority suffer from language anxiety in the classroom. Seventeen percent $(\mathrm{n}=11)$ of the participants obtained scores between 133 and 165; 73\% $(\mathrm{n}=48)$ obtained scores between 100 and 132; and 10\% $(\mathrm{n}=7)$ obtained scores between 67 and 99 . Overall, $90 \%$ of the participants experienced high levels of anxiety.

\section{Insert Table 4 about here}

Weinstein and Mayer (1986) define learning strategy broadly as "behaviors and thoughts that a learner engages in during learning" which are "intended to influence the learner's encoding process" (p.315). Oxford (1992) indicates that language learning strategies are specific actions, behaviors, steps, or techniques that students use to improve their progress in developing L2 skills. These strategies are tools for the self-directed involvement necessary for developing communicative ability.

The results (Table 5) in the present study reveal that Group 1 learners (higher English proficiency) use various learning strategies more frequently than students in Group 2. Item 1: reading aloud (Group 1, M=3.12; Group 2, M=2.79); Item 2: consciously learning new vocabulary (Group 1, $\mathrm{M}=3.76$; Group 2, $\mathrm{M}=3.0$ ); Item 3: making a sentence when learning a new word (Group 1, $\mathrm{M}=3.55$; Group 2, $\mathrm{M}=2.98$ ); Item 4: using English-English dictionary (Group 1, $\mathrm{M}=2.99$; Group 2, $\mathrm{M}=2.23$ ); Item 5: trying to think in English (Group 1, $\mathrm{M}=2.99$; Group 2, $\mathrm{M}=2.88$ ); Item 6: skimming (Group 1, $\mathrm{M}=3.28$; Group 2, $\mathrm{M}=3.14$ ); Item 7: predicting or guessing (Group 1, $\mathrm{M}=3.12$; Group 2, $\mathrm{M}=2.77$ ); Item 8: learning from mistakes (Group 1, $\mathrm{M}=3.89$; Group 2, $\mathrm{M}=3.90$ ); Item 9: using synonym or antonym (Group 1, $\mathrm{M}=3.13$; Group 2, $\mathrm{M}=2.96$ ); Item 10: setting learning goals (Group1, $\mathrm{M}=3.18$; Group 2, $\mathrm{M}=2.69$ ); Item 11: learning from the teacher (Group 1, $\mathrm{M}=4.0$; Group 2, $\mathrm{M}=4.16$ ); Item 12: reading newspaper in English (Group 1, $\mathrm{M}=2.67$; Group 2, $\mathrm{M}=2.35$ ); Item 13: watching TV in English (Group 1, $\mathrm{M}=4.11$; Group 2, $\mathrm{M}=4.09$ ); Item 14: reading English magazines for pleasure (Group 1, $\mathrm{M}=3.85$; Group 2, $\mathrm{M}=3.06$ ); Item 15: listening to the radio in English (Group 1, $\mathrm{M}=3.46$; Group 2, $\mathrm{M}=3.23$ ); Item 16: discussing with classmates (Group 1, $\mathrm{M}=4.18$; Group 2, $\mathrm{M}=3.75$ ); Item 17: making friends with native speakers (Group 1, M=2.46; Group 2, $\mathrm{M}=1.59$ ); Item 18: Self-assessment (Group 1, M=2.68; Group 2, M=1.99).

The results above reveal that only two items (item 8: learning from mistakes and item 11: learning form the teacher) in Group 2 obtained higher mean scores than Group 1. Most of the other items in Group 1 have higher mean scores than those in Group 2. Oxford (1992) indicates that successful learners generally employ a larger variety of learning strategies more frequently than do poor learners. To help students learn better, it is important to take into account the language learning strategies in the teaching/learning of English.

\section{Insert Table 5 about here}

\section{Discussion}

Classrooms are not only places where students learn, they are also places where teachers can learn. In the present study, both quantitative and qualitative analyses are applied to help teachers understand better student attitudes and perceptions vis-à-vis learning strategies and language anxiety in the CLT classrooms. Although $86 \%$ of participants had a positive attitude, $62 \%$ had some reservations. To get a more complete picture of their perception, a 20 -miniute interview was given to eight select participants, four male and four female. The eight participants included four freshmen, and four sophomores. Four of them were in Group 1, and whose English proficiency was better than the four in Group 2: F1(Andrew), S1 (Dilan), F2( Mark), S2(Jay), F3(Mary), S3(Jennifer), F4(Alice), and S4(Doris). The interviews were recorded and then transcribed. The interview questions were mainly from COLTAS, FLCAS, and SILL. The ultimate aim of the interview was to understand their perceptions vis-à-vis learning English in a student-centered, CLT classroom.

Based on the results, the participants in the present study show favorable attitudes toward CLT. The interviews reveal 
that traditional grammar-translation teaching methodology and teacher-centered learning offer the select participants little opportunities to practice the target language in the classroom. Most of their time has been spent preparing for tests. Although students are good at memorizing vocabulary and grammatical rules, they indeed have difficulties learning real-life communicative English. They reveal that they seldom use English as a communication medium in their daily life. In their previous learning experience, local English teachers ask them to memorize a lot of vocabulary and phrases, and analyze grammar rules for them. Affected by the pressure of examinations, they seldom communicate in English in the classroom or after class. L1 is used most of the time in the foreign language classroom. That is one of the causes of student reticence. Kouraogo (1993) attributes students' poor English performance to the lack of opportunity, and claims that it is a major factor in poor environments, where English is seldom used outside the classroom. Most of the participants reveal that native teachers prefer adopting a student-centered approach along with more discussion and presentation. Students who are used to traditional teacher-centered model would have difficulties adapting themselves to an innovative learning environment.

Although discussion is a kind of productive language practice, some of the participants regard it as useless. One of the freshmen (Mary) indicates that pair/group activity certainly motivates and inspires them to practice English in the classroom. The outcome, however, fails to meet their expectations.

F3 (Mary): I agree that pair/group work could motivate shy students to be involved in the discussion, and provide us with more chances to practice English. But, L1 is often used more than the target language during the process of our practice (April 11, 2009).

One of the sophomores notes that teacher correction is more efficient than peer correction. One of the main reasons for this is their deficiency in spoken English.

S3 (Jennifer): Although peer correction may increase more interaction between students, I am concerned about its efficiency. The reason is that our English level is not good enough to correct other's mistakes (April 11, 2009).

Another freshman (Andrew) points out that low English proficiency is the cause of their reticence in the classroom, though they are willing to communicate with teachers or their classmates; limited English proficiency becomes one of their major constraints when they are conducting group work or peer correction.

F1 (Andrew): I love to chat with my teachers and classmates, but I feel that I still lack confidence when I use English as the communication medium. I choose English as my major because I have a very strong desire to improve my English proficiency. I am very anxious when I am going to speak in front of the whole class (April 11, 2009).

In addition, most agree that teaching should emphasize language use rather than language rules. Nevertheless, the grammar instruction cannot be completely avoided if it enables students to use English more correctly. F3(Mary) reveals her worry by saying that proper grammatical correction is necessary, because she doesn't know what mistakes she has made.

Learning a foreign language, anxiety is one of the shared experiences, especially for language learners in the EFL context. Communication apprehension, test anxiety, and negative evaluation have impacted language learners profoundly. The interviews reveal that sources of anxiety are often intertwined. For example, teachers, activities, pedagogical practices, and evaluation are plausible anxiety-provoking factors in the language classroom. When asked their perception of native teachers, positive and negative comments co-exist. "Authenticity" or "real model" is said to account for the status of native teachers. Another sophomore (Dilan) notes that native teachers offer them a real model to follow, and a real context to use English, when compared to non-native teachers. But, he adds that native teachers do not perform as well as non-native teachers in terms of grammar knowledge. In addition, native teachers rarely acquaint themselves with the students' native language. Thus, native teachers can hardly anticipate and predict students' difficulties in the learning process. By contrast, non-native teachers usually can foretell students' learning pitfalls and thus provide a good learner model to their students.

S1 (Dilan): I feel more anxious when I speak to native teachers compared to non-native teachers. Fortunately, our native teacher is very kind and humorous. I love to ask questions though my English is very poor. Non-native teachers are also very good, but I prefer being taught by native teachers. When I talk to non-native teachers, I will rely on L1 more. When I talk to native teachers, I can only use English (April 11, 2009).

Medgyes (1994) claims that both native and non-native teachers could be successful EFL/ESL teachers. He states that an ideal native teacher is one who has achieved a high degree of proficiency in the learners' mother tongue; an ideal non-native teacher is one who has achieved near-native proficiency in English (p.348-349).

The role of teachers in the language classroom, suggested by one of the freshmen (Alice), ought to be one who alleviates students' anxiety and provides them with supportive and non-threatening teaching methods.

F4 (Alice): Although I have learned English for over six years, I have problems communicating with native speakers. In the previous learning experience, I have never been taught by native teachers, and most of the local teachers use L1 to 
explain a lot about English grammar. I am very nervous when I face to native teacher for the first time in the classroom. I feel very stressful at the very beginning, but now I am more used to chatting with native teachers (April 12, 2009).

One of the freshmen (Mark) notes that it will be difficult for them to learn efficiently in a stressful atmosphere. One of the sophomores (Doris) reveals her frustration and uneasiness when giving a presentation in front of the class. She suffers from stress, mentally and physically. Another sophomore (Jay) notes that a more humorous teacher is usually popular because $\mathrm{s} /$ he makes the class more fun or relaxed.

Mark, Doris, Jay: We have to work Monday through Friday, and we have very little time to practice English. We feel very stressful because we have a lot of assignments, such like quiz and presentation. Some of our classmates perform very well in the class because of their occupation. Some of them have to use English almost every day, but we seldom use English in our working place. We are very motivated to learn, but we also suffer from frustration sometimes. In summary, a less anxious learning environment will be very helpful to us (April 12, 2009).

Language learners who are free from pressure show more confidence and willingness to practice in the classroom. In other words, language must be acquired naturally just as a child who picks up her/his first language. Krashen (1985) promotes the Affective Filter Hypothesis to stress the importance of building a classroom environment that is less threatening to anxious students. It is particularly important to reduce anxiety for learners with low proficiency and confidence.

Although most of the participants in this study show positive attitudes toward CLT, they also have a high level of anxiety in the classroom. As shown in Table 4, four male participant and three female participants show more confidence than the rest. Most of the participants experience different levels of anxiety in the classroom. Through interviews, the select eight participants share their opinions on learning strategies and their perception of the relationship between learning strategies and language anxiety. Four of the select participants in Group 1 show more confidence than the other four in Group 2. The findings reveal that those students who have expended much effort and time studying English tend to use a larger variety of learning strategies more frequently and they feel less anxious when they use English. One of the interviewees indicates that he likes to watch movies or TV programs in English every day because he finds it pleasurable to learn English in a more relaxed setting.

F3 (Mary): I usually watch movie spoken in English on TV after work. I try not to look at the Chinese translation, because I want to put myself in an entire English-only environment. On the one hand, I may use it to increase my listening comprehension; on the other hand, I treat it as a relief from pressure after work. Besides, I love to think in English and talk to my friends in English. I feel that the more time I expose myself to the L2 context, the less anxious I will feel (April 11, 2009).

S3 (Jennifer), S4 (Doris), and F2 (Mark) support Mary's arguments in terms of their own learning strategies.

S3 (Jennifer): I usually take advantage of every possible moment to read an English newspaper and take notes. I need to write a report in English, and communicate with my clients outside of Taiwan in English. I feel more and more confident and less and less anxious because I use the target language every day (April 11, 2009).

S4 (Doris): I am a salesperson in a business company. I have to do a lot of presentations, either in Chinese or in English. It made me feel very nervous at the very beginning, so I spent much time practicing at home. My family members were my audience, and they offered suggestions to make me feel more comfortable and less anxious when giving a presentation in front of a large group of people (April 12, 2009).

F2 (Mark): I consciously learn new English words every day, because it will be very helpful when I read English magazines or listen to English songs (April 12, 2009).

The above four participants who use the target language more frequently are more confident and less anxious. On the contrary, those who use less frequently the target language have higher level of anxiety. One of the participants notes that English proficiency seems to influence his learning strategy.

F1 (Andrew): I have difficulty understanding English programs without the assistance of Chinese captions. I use an English-Chinese dictionary most of the time and seldom use an English-English dictionary when I come across a new word. I really want to improve my English ability, but I don't have enough time to practice (April 11, 2009). The other three participants -- Dilan, Alice, and Jay-- also express their learning problems.

S1(Dilan): I try to think in English, but it is too hard for me. My English is very poor. I speak English only in the classroom (April 11, 2009).

F4(Alice): I never keep a diary in English. I seldom use English to communicate with my colleagues in the office (April 12, 2009).

S2 (Jay): I learn English from my English teachers. I have no foreign friends, so I feel nervous when I talk to native speakers (April 12, 2009). 
The results above indicate that motivation, effort, and English proficiency have significant influence on their leaning strategies and levels of anxiety. In addition, factors such as the participants' gender, age, employment status, years of leaning English, time to study English outside the classroom play a major role in mastery of English. In the case of gender, for example, females show higher levels of anxiety than males. Female participants become nervous when asked to answer questions in class, especially when they are singled out or have to give a presentation. They worry about their English proficiency and making mistakes in front of the class. But, they feel less anxious when they are in a pair or group. Regarding age, participants between 24 and 30 years old have lower levels of anxiety than older participants. The finding reveals that participants aged 51 to 60 prefer a teacher-centered teaching model to a student-centered model, while younger participants are more likely to accept an innovative teaching approach. As to employment status, those who work in the business and education fields show lower levels of anxiety in the classroom. When asked about the reasons they feel less anxious in the language classroom, the three participants who got the lowest scores all refer to the importance of environment, especially the frequency of exposure to the target language. Because of their occupation, these three participants have a lot of chances to communicate with people from different cultures. They are more attuned to diverse accents and feel less anxious when English is the main communication medium. In other words, the higher the frequency L2 is used, the lower the anxiety. The results also indicate that participants who have studied English for more than ten years have more confidence, and participants who use English outside the classroom more than 15 hours per week show lower levels of anxiety.

\subsection{Pedagogical implication and Suggestion}

CLT puts the focus on the learner. The role of the teacher is that of a facilitator, advisor, and co-communicator. The role of the students is to communicate by participating in meaning-negotiation activities and to manage their own learning. CLT will fail if teachers have an unfavorable attitude toward it and do not believe that this approach will work for them. In this study, both native teachers surveyed had a positive attitude to CLT. One of the native teachers notes that he prefers adopting activities such as pair/group discussion as well as peer correction to motivate students' participation and generate more interaction in the classroom.

Luke: I love to teach weekend program students, you know, they are mature and full of motivation. Although their English proficiency is not very good, their attitude is great, compared to my day-time students. I usually try to make them feel comfortable and encourage them to practice English in the class. Most of them perform well, and we have wonderful interaction (April 18, 2009).

Although some of the participants are very anxious and shy when assigned to speak in class, they have a positive attitude and strong motivation to practice English. It is very pleasant to adopt the CLT approach in a reading class, says another native teacher.

Edward: The students in my class are eager to improve their English ability, although some of them are very shy and nervous. I love to do pair or group activities to motivate them to practice English in the class. In the beginning, they are not used to being assigned an activity. After a while, however, they enjoy discussing with each other in class. I try not to correct their mistakes most of the time during their discussion. Fluency is more important than accuracy at the first stage for language learners (April 19, 2009).

Although CLT is one of the popular teaching approaches, there are still some controversies. For example, the word "fluency" in contrast to "accuracy" has been widely used in CLT. In CLT, fluency refers to effectiveness of language use within the constraints of limited linguistic knowledge. The notion of fluency is used to assess how well learners use their knowledge to achieve their linguistic and communicative goals. Fluency is a commonly used notion in foreign language teaching and yet it is a concept that is difficult to define precisely (Chambers, 1997). As to teacher correction, it is a dilemma for teachers when they meet learner errors in CLT. Truscott (1999) advocates total rejection of any type of corrective feedback. Krashen (1985) argues that grammar can only be acquired naturally through exposure to the target language, so that special attention should be given to the meaning, not the form. To bridge the gap, Ellis (1994) suggests the method known as "recast" as a way to reformulate a learner's incorrect utterance while maintaining a focus on meaning. Savignon (1991) reveals that research overwhelmingly supports the integration of form-focused exercises with meaning-focused experience. Grammar is important; and learners seem to focus best on grammar when it relates to their communicative needs and experiences (p.269). Regarding this contradiction, Wu (2008) concludes that CLT should not be conceptualized as a teaching approach that is intended to exclude form but rather one that is intended to include communication. Therefore, any extreme pedagogical practice should be avoided.

As mentioned earlier, non-native teachers offer students a learner model during the learning process. Thus, L1 is used as a useful communication medium when L2 learners have difficulty finding English equivalents. The argument vis-à-vis the use of L1 or L2 has been very heated. Lightbrown (1991) points out that successful learners need as much exposure to the target language as possible and thus L1 should be used sparingly. Swain and Lapkin (2002) show the opposite perspectives, and report that the use of L1 will facilitate learners to achieve linguistic goals. Although there are diverse interpretations and explanations in terms of the efficiency of using L1, it is vital for teachers to take into account the 
needs of students and find the most appropriate way to balance the use of L1 and L2.

The interviews with the participants reveal that the role of the teacher is paramount in the language classroom. Savignon (1991) points out the teachers' different feelings about CLT:

Depending upon their own preparation and experience, teachers themselves differ in their reactions to CLT. Some feel understandable frustration at the seeming ambiguity in discussions of communicative ability. Negotiation of meaning is well and good, but this view of language behavior lacks precision and does not provide a universal scale for assessment of individual learners. Ability is viewed, rather, as variable and highly dependent upon context and purpose. Other teachers welcome the opportunity to select and/or develop their own materials, providing learners with a range of communicative tasks. And they are comfortable relying on more global, integrative judgments of learner progress (p.266).

In the EFL context, native teachers in the classroom are regarded as one of the anxiety-provoking factors. Regarding the command of language, native teachers are likely to adopt CLT more smoothly than local English teachers. The number of non-native English speaking teachers, however, is larger than native English speaking teachers. Canagaraiah (1999) points out that $80 \%$ of the English teachers in the world are non-native speakers. In the EFL context, native teachers offer language learners a "foreign model" and thus become the preferred choice. On the contrary, non-native teacher provide language learners a "learner model", whose learning experience would encourage learners to learn language more efficiently. In the CLT classroom, both native and non-native English speaking teachers may encounter different problems. Cook (1999) argues that language teaching would benefit by paying attention to the L2 user rather than concentrating primarily on the native speaker. Braine (2005) claims that one group of teachers should not necessarily be superior to the other group. To help learners to learn better, simultaneous team teaching could be one of the choices in the EFL context. The focus is on the cooperation between native and non-native instructors, and its main goal is to assist students to learn the target language more efficiently. It has proved to be effective in international school settings (Pardy, 2004) and has been implemented in TEFL or TESL situations, particularly in Japan (TAJino \& Tajino, 2000) and Hong Kong (Lai, 1999).

In addition to teaching strategies, the adaptation of language learning strategies (LLS) to language learners is also necessary and important. LLS are useful for learners because they are tools for active, self-directed involvement, which is essential for developing communicative competence (Oxford, 1990a). It is also crucial for language teachers to use LLS in the classrooms to help L2 learners understand the language learning process to improve their skills. Participants in this study are mature students with working experience; however, many of them still suffer from anxiety in the language classroom. To help them learn better, it is very important to create a more friendly and supportive learning environment. Teachers need to be sensitive to learners' fears and insecurities and help them to overcome those fears. Encouragement and non-threatening instruction are good ways to ease learner anxiety and enhance their motivation. Foreign language anxiety is a distinct and specific state anxiety. Learner self-esteem, language testing, teacher attitudes, peer competiveness, academic levels, the experience of visiting a FL country, gender differences, and work experience are possible sources that contribute to learner FL anxiety. It will be hard for learners to take active roles in class when they have difficulties using the target language. If language learners have fewer problems with language, both in perception and production, they are more likely to take active roles in class. The most important thing that teachers should be concerned about is finding ways to improve their teaching skills and to handle challenges such as professional training, linguistic and sociolinguistic competence, and understanding better the needs of students.

\section{Conclusion}

The results of this study reveal that both teachers and students hold positive attitudes toward CLT, in spite of reservations. Although there are a lot of difficulties in its implementation, CLT is still feasible teaching approach that can certainly be applied in the EFL context. At the tertiary level, everyone concerned needs to explore strategies for encouraging students to move ahead towards more active roles. Student concerns about active speech roles and teachers' desire for them to move away from passive learning appear to fit well into the learner-centered philosophy. Researchers (Campbell and Zhao, 1993; Eveyik-Aydin, 2003; Hu, 2002; Li, 1998) have warned against total and unbridled adoption of CLT and called attention to the need for considering the socio-cultural milieu of the teaching context where CLT is being implemented. As Hu (2002) contends, "it is important for educational policymakers and teachers to take a cautiously eclectic approach and make well-informed pedagogical choices that are grounded in an understanding of socio-cultural influences" (p. 103). Any teacher who plans to use methodologies which inevitably involve student participation should make sure that the students are familiar with and accept such methodologies.

There are still some arguments about CLT to be considered. For instance, the focus on meaning against form; fluency vs. accuracy; and inclusion vs. avoidance of L1. Although contradictions regarding the feasibility of CLT persist, it is more important to take into account the needs of students. During the learning process, anxiety seems to be an obstacle to English acquisition. The impact of anxiety-provoking causes should be taken into consideration. It is the teachers' duty to create a less threatening atmosphere, to motivate, and to strengthen student confidence. More motivated students tend 
to be more successful language learners. More importantly, both teachers and students should be fully aware of the importance of LLS in the CLT classrooms and adopt the most efficient learning/teaching approaches.

\section{References}

Aida, Y. (1994). Examination of Horwitz, Horwitz, and Cope's construct of foreign language anxiety: The case of students of Japanese, Modern Language Journal , 78(2), 155-168.

Alpert, R., \& Haber, R. (1960). Anxiety in academic achievement situations. Journal of Abnormal and Social Psychology, 61, 207-213.

Braine, G. (Ed.). (2005). Teaching English to the world. History, curriculum, and practice. Mahwah, NJ: Laurence Erlbaum Associates.

Brown, H. D. (2000). Principles of language learning and teaching. New York: Addison Wesley Langman.

Burnaby, B. \& Sun, Y. (1989). Chinese teachers' views of Western language teaching: Context informs paradigm. TESOL Quarterly, 23, 219-238.

Campbell, K. \& Zhao, Y. (1993). The dilemma of English language instruction in the People's Republic of China. TESOL Journal, 2(4), 4-6.

Canagarajah, A. S. (1999). Interrogating the "native speaker fallacy": Non-linguistic roots, non-pedagogical results. In G. Braine (Ed.) Nonnative educators in English language teaching (pp. 77-92). Mahwah, NJ: Erlbaum.

Chambers F. (1997). What do we mean by fluency? System, 25(4), 535-544.

Chamot, A. U., Barnhardt S., El-Dinary, P. B. \& Robbins, J. (1999). The learning strategies handbook. White Plains, NY: Addison Wesley Longman.

Cheng, Y. S. (2002). Factors associated with foreign language writing anxiety. Foreign Language Annals, 35(6), 647-656.

Cook V. (1999). Going Beyond the Native Speaker in Language Teaching. TESOL Quarterly, 33(2), p.185.

Copeland H. ( 1952). A Student-centered Program: The Program in Practice at Franklin and Marshall College. The Journal of Higher Education. 23(3), pp. 145-172.

Cortazzi, M. \& Jin, L. (1996). Cultures of learning: language classrooms in China. In Coleman, H. (Ed.), Society and the Language Classroom. Cambridge University Press, pp. 169-206.

Crookall, D. \& Oxford R. (1991). Dealing with anxiety: Some practical activities for language learners and teacher trainees. In E. K. Horwitz \& D. J. Young(Eds.), Language Anxiety: From theory and research to classroom implications (pp.141-148). Englewood Cliffs, NJ: Prentice Hall.

Elkhafaifi, H. (2005). Listening comprehension and anxiety in the Arabic language classroom. The Modern Language Journal, 89(2), 206-220.

Ellis, R. (1994). The Study of Second Language Acquisition. Oxford University Press, Oxford.

Eveyik-Aydin, E. (2003, March). EFL teacher's voice on communicative language teaching. Paper presented at the Annual Meeting of Teachers of English to Speakers of Other Languages. Baltimore, Maryland.

Ewald, J. D. (2007). Foreign language learning anxiety in upper-level classes: Involving students as researchers. Foreign Language Annals, 40(1), 122-142.

Ferris, D. \& Tagg. T. (1966). Academic listening/speaking tasks for ESL students: problems, suggestions, and implications. TESOL Quarterly, 30(2), 297-320.

Flowerdew, J. \& Miller, L. (1995). On the notion of culture in L2 lectures. TESOL quarterly, 29(2), 345-373.

Gardner, R. C. (1985). Social psychology and second language learning: The role of attitudes and motivation. London: Edward Arnold.

Gardner, R. C. \& W. E. Lambert (1972). Attitude and Motivation in Second Language Learning. Rowley, MA: Newbury House.

Goldberg, L. R. (1993). The structure of phenotypic personality trait. American Psychologist, 48, 26-34.

Gregersen, T. (2003). To err is human: A reminder to teachers of language-anxious students. Foreign Language Annals, $36,25-32$.

Horwitz, E. K., Horwitz, M. \& Cope, J.(1986). Foreign language classroom anxiety, The Modern Language Journal, 70(2), 125-132.

Hu, G. (2002). Recent important developments in secondary English-language teaching in the People's Republic of 
China. Language, Culture, Curriculum, 15, 30-49.

Huang, Y. K. (1990). Developing your students' communicative competence: Some practical ideas for classroom teachers. In Selected Papers from the Ninth Conference on English teaching and learning in ROC, 54-64. Taipei: The Crane Publishing Co., Ltd.

Hymes, D. (1972). On communicative competence. In J. B. Pride, \& J. Holmes (Eds.), Sociolinguistic. Harmondsworth: Penguin.

Jones, J. (1999). From silence to talk: cross-cultural ideas on students' prticiption in academic group discussion. English for Specific Purposes, 18(3), 243-259.

Kachru, B. (1997). World Englishes and English-using communities. Annu. Rev. Appl. Linguist. 17, 66-87.

Karavas-Doukas, E. (1996). Using attitude scales to investigate teachers' attitude to the communicative approach. ELT Journal, 50, 187-198.

Kouraogo, P. (1993). Language learning strategies in input-poor environments. System, 21(2), 165-173.

Krashen, S. D. (1985b). The input hypothesis: Issues and implications. New York: Longman.

Krashen, S. D. \& Tracy D. T. (1983). The Natural Approach: Language Acquisition in the Classroom. Englewood Cliffs, NJ: Alemany Press.

Kubota, R. (1999). Japanese culture constructed by discourses: implications for applied linguistics research and ELT. TESOL Quarterly, 33 (1), 9-35.

Lai, M. (1999). Hong Kong: Language and education in a post-colonial era. Language, Culture Curriculum, 12(3), 191-195.

Li, D. (1998). "It's always more difficult than you plan and imagine": Teachers' perceived difficulties in introducing the communicative approach in South Korea. TESOL Quarterly, 32, 677-703.

Lightbrown, P. M. (1991). Getting quality input in the second/foreign language classroom. In C. Kramsch \& S. McConnell-Ginet (Eds.). Text and context: Cross-disciplinary perspectives on language study (pp.187-197). Lexington, Mass: D. C. Heath and Company.

Littlewood, W. T. \& Liu, N. F. (1997). Why do many students appear reluctant to participate in classroom learning discourse? System, 25(3), 371-384.

MacIntyre, P. D., Cle'ment, R., D”ornyei, Z. \& Noels, K. A. (1998). Conceptualizing willingness to communicate in a L2: a situational model of L2 confidence and affiliation. Modern Language Journal, 82, 545-562.

MacIntyre, P. D. \& Gardner, R. C. (1991). Methods and results in the study of anxiety and language learning: A review of the literature. Language Learning, 41(1), 85-117.

MacIntyre, P. D. \& Gardner, R. C. (1994). The subtle effects of language anxiety on cognitive processing in the second language. Language Learning, 44, 283-305.

Matsurra, H., Chiba, R. \& Hilderbrandt, P. (2001). Beliefs about learning and teaching communicative English in Japan. JALT Journal, 23, 69-89.

Nimmannit, S. (1998). Maximizing students' oral skills: The Asian context. Language Teacher online journal. From http://www.jalt-publications.org/tlt/files/98/nov/nimmannit.html

Nunan, D. (2003). The Impact of English as a Global Language on Educational Policies and Practices in the Asia-Pacific Region. TESOL Quarterly, 37(4),610.

Oxford, R. (1992). Language learning strategies in a nutshell: Update and ESL suggestions. TESOL Journal, 2(2), $18-22$.

Oxford, R. (1999). Anxiety and the language learner: New insights. In J.Arnold (Ed.), Affect in language learning (pp. 58-67). Cambridge, United Kingdom: Cambridge University Press.

Pardy, D. (2004). The perceived effectiveness of simultaneous team-teaching in a dual language programme. Journal of Research in International Education, 3(2),207-224.

Phillips, E. M. (1992). The effects on language anxiety on students' oral test performance and attitudes. The Modern Language Journal. 76(1), 14-26.

Phillips, E. M. (1999). Decreasing language anxiety : Practical techniques for oral activities. In D. J. Young (Ed.), Affect in foreign language and second language learning. A practical guide to creating a low-anxiety classroom atmosphere (pp.124-143). Boston: McGraw-Hill.

Price, M. L. (1991). The subjective experience of foreign language anxiety: Interviews with highly anxious students. In 
E. Horwitz \& D. Young (Eds.), Language learning anxiety: From theory and research to classroom implications (pp. 101-108). Englewood Cliffs, NJ: Prentice Hall.

Rao, Z. (2002). Chinese students' perceptions of communicative and non-communicative activities in EFL classroom. System, 30, 85-105.

Reid, J. (1995). Learning styles in the ESL/EFL classroom. Boston: Heinle \& Heinle.

Saito, Y. \& Samimy, K. K. (1996). Foreign language anxiety and language performance: A study of learner anxiety in beginning, intermediate, and advanced-level college students of Japanese. Foreign Language Annals, 29(2), 239-251.

Samimy, K. (1994). Teaching Japanese: Consideration of learners' affective variables. Theory into Practice, 33(1), 29-33.

Savignon, J. (1991). Communicative Language Teaching: State of the Art. TESOL Quarterly, 25(2), 261-277.

Sellers, V. D. (2000). Anxiety and reading comprehension in Spanish as a foreign language. Foreign Language Annals. 33(5), 512-521.

Skehan, P. (1989). Individual differences in second-language learning. London: Edward Arnold.

Spielberger, C. (1966). Anxiety and behavior. New York: Academic Press.

Spielberger, C. (1983). Manual for the state-trait anxiety inventory. Palo Alto,CA: Consulting Psychologist Press.

Swain, M. \& Lapkin, S. (2002). Talking it through: Two French immersion learners' response to reformulation. International Journal of Educational Research, 37, 285-304.

Tajino, A. \& Tajino, Y. (2000). Native and non-native: what can they offer? Lessons from team-teaching in Japan. ELT Journal, 54(1),-11.

Tallon, M. (2009). Foreign Language Anxiety and Heritage Students of Spanish: A Quantitative Study. Foreign Language Annals, 42(1), 112-137.

Truscott, J. (1999). What's wrong with oral grammar correction? Canadian Modern Language Review, 55, 437-456.

Tudor, T. (1998). Rationality and rationalities in language teaching. System, 26(3), 319-334.

Turner, J. \& Hiraga, M. K. (1996). Elaborating elaboration in academic tutorials: changing cultural assumption. In J. Coleman and L. Cameron (Eds.), Change and Language, pp.131-140. BAAL and Multilingual Matters, Clevedon.

Tusi, A. (1996). Reticence and anxiety in second language learning. In Bailey, K., Nunan, D. (Eds.), Voices from the Language Classroom. Cambridge University Press, Cambridge, pp. 145-167.

Webb, C. \& Baird, H.(1968). Differences Resulting from Teacher- and Student-Centered Teaching Methods. The Journal of Higher Education, 39(8), 456-460.

Weinstein, C., \& Mayer, R. (1986). The teaching of learning strategies. In M.C. Wittrock (Eds.), Handbook of Research on Teaching, $3^{\text {rd }}$ Edition (pp. 315-327). New York: Macmilan.

Wu, W. (2008). Misunderstandings of Communicative Language Teaching. English Language Teaching, 1(1), 50-53.

Yashima, T. \& Zenuk-Nishide, L. (2004). The influence of attitude and affect on willingness to communicate and second language communication. Language Learning, 54, 119-152.

Young, D. J. (1999). Affect in foreign language and second language learning: A practical guide to creating a low-anxiety classroom atmosphere. Boston: McGraw-Hill.

Young, D. J. (1992). Language anxiety from the foreign language specialists' perspective: Interviews with Karshen, Omaggio, Hadley, Terrell, and Rardin. Foreign Language Annals, 25, 157-172.

Young, D. J. (1994). New directions in language anxiety research. In C. A. Klee (Ed.), Faces in a crowd: The individual learner in multi-section courses (pp. 3-46). Boston: Heinle \& Heinle.

Appendix A

1.Language classes should be student-centered, not teacher centered.

2.P air work activities should be avoided as it is difficult for teachers to monitor each student's performance.

3. Teacher correction should be avoided when it interrupts the flow of communication via student interaction.

4.An orderly teacher centered class is necessary for students to get maximum benefit from teacher input in English.

5. Students need to have immediate teacher feedback on the accuracy of the English they produce.

6. Pair work develops oral conversational skills in English.

7. Group work creates a motivating environment to use English.

8. Teachers should allow opportunity for student-student correction in English.

9. The major role of teachers is to transmit knowledge about language to students through explanations rather than to guide them for self-learning. 
10. Teacher feedback should be mainly focused on the content of the activity not on the form of language.

11. It is of great importance that student responses in English be grammatically accurate.

12. Teachers should be the initiators of most interactions in English in the class.

13. To develop communicative skills, explicit grammar teaching is not necessary.

14. Emphasis should be on language use rather than language rules while teaching English in the class.

15. Pair work provides a greater amount of student involvement than a teacher-led activity.

16. Group work helps those students who are not willing to speak in front of a full class.

17. Focus on communicative competence produces linguistically inaccurate speakers of language.

18. Teachers should make an analysis of student needs in order to design suitable tasks and activities in English.

19. .Group work causes a noisy classroom atmosphere which prevents meaningful practice in English.

20. .Teacher feedback should be mainly focused on the appropriateness of the student responses rather than the linguistic accuracy of the forms.

21. Teachers should not tolerate mistakes in English forms.

22 .Meaning focused activities are more effective to develop communicative ability than form-focused activities.

23. Students' attention should be drawn to the linguistic system of English through direct teaching of the structures.

24. Group work cannot increase the amount of English practice because the students tend to use their native language while working in groups.

25. Teacher correction should be provided only when it is required for effective communication.

26. Pair work is not an effective means of improving communication skills in English.

27. Helping students develop the use of context-appropriate language should be the primary goal of language teaching.

28. Students' language performance should be primarily judged by their grammatical correctness.

29. To learn how to communicate effectively, a considerable amount of time should be spent on grammatical explanations.

30. Since students have little information about the language, they should not be allowed to correct their peers' mistakes.

31. Most of the interaction in the class should be from students to students, not from teachers to students.

32. A teacher-directed class will motivate students to work productively with English.

33. Grammar teaching may be included in a lesson as a means of communication, not as the main goal of teaching.

34. Group work increases the quantity of oral/aural language practice.

35. Correction should be mainly focused on the mistakes in language structures.

36. Pair work cannot create a motivating environment to use English.

\section{Appendix B}

1. I never feel quite sure of myself when I am speaking English in my class.

2. I don't worry about making mistakes in the English class.

3. I tremble when I know that I'm going to be called on in the English class.

4. It frightens me when I don't understand what the teacher is saying in English.

5. It wouldn't bother me at all to take more foreign language classes.

6. During my English class, I find myself thinking about things that have nothing to do with the course.

7. I keep thinking that the other students are better at English than I am.

8. I am usually at ease during English tests in my class.

9. I start to panic when I have to speak without preparation in the English class.

10. I worry about the consequences of failing my English class.

11. I don't understand why some people get so upset over English classes.

12. In the English class, I can get so nervous I forget things I know.

13. It embarrasses me to volunteer answers in my English class.

14. I would not be nervous speaking English with native speakers.

15. I get upset when I don't understand what the teacher is correcting.

16. Even if I am well prepared for the English class, I feel anxious about it.

17. I often feel like not going to my English class.

18. I feel confident when I speak English in class.

19. I am afraid that my English teacher is ready to correct every mistake I make.

20. I can feel my heart pounding when I'm going to be called on in the English class.

21. The more I study for an English test, the more confused I get.

22. I don't feel pressure to prepare very well for the English class.

23. I always feel that the other student speak English better than I do.

24. I feel very anxious about speaking English in front of other students.

25. The English class moves so quickly I worry about getting left behind.

26. I feel more tense and nervous in my English class than in my other classes.

27. I get nervous and confused when I am speaking English in class.

28. When I'm on my way to the English class, I feel very sure and relaxed.

29. I get nervous when I don't understand every word the English teacher says.

30. I feel overwhelmed by the number of rules I have to learn to speak English. 
31. I am afraid that the other students will laugh at me when I speak English.

32. I would probably feel comfortable around native speakers of English.

33. I get nervous when the English teacher asks questions which I haven't prepared in a advance.

\section{Appendix $\mathrm{C}$}

1. I usually read English aloud.

2. I consciously learn new English vocabulary.

3. I usually make a sentence when learning a new word.

4. I use an English-English dictionary when I come across a new word.

5. I try to think in English.

6. I usually skim an article and then read it again carefully.

7. I usually use prediction or guessing when I learn English.

8. I usually learn from mistakes.

9. I usually use synonym or antonym.

10. I set learning goals and plans in the process of learning English.

11. I usually learn from the teachers.

12. I usually read newspaper in English.

13. I usually watch TV spoken in English.

14. I usually read English magazines for pleasure.

15. I usually listen to the radio in English.

16. I usually discuss with my classmates in English.

17. I make friends with native speakers.

18. I usually self-evaluate my learning process.

Table 1. Background of Participants

\begin{tabular}{|c|c|c|c|c|c|}
\hline Characteristic & & & & & \\
\hline Gender & $\begin{array}{l}\text { Male } \\
(25,38 \%)\end{array}$ & $\begin{array}{l}\text { Female } \\
(41,62 \%)\end{array}$ & & & \\
\hline Age & $\begin{array}{l}24-30 \\
(20,30 \%)\end{array}$ & $\begin{array}{l}31-40 \\
(23,35 \%)\end{array}$ & $\begin{array}{l}41-50 \\
(19,29 \%)\end{array}$ & $\begin{array}{l}51-60 \\
(4,6 \%)\end{array}$ & \\
\hline Employment Status & $\begin{array}{l}\text { Soldier } \\
(2,3 \%)\end{array}$ & $\begin{array}{l}\text { Public servant } \\
(14,21 \%)\end{array}$ & $\begin{array}{l}\text { Educator } \\
(8,12 \%)\end{array}$ & $\begin{array}{l}\text { Business } \\
(23,35 \%)\end{array}$ & $\begin{array}{l}\text { Other } \\
(19,29 \%)\end{array}$ \\
\hline Years of Learning English & $\begin{array}{l}1-10 \\
(37,56 \%)\end{array}$ & $\begin{array}{l}11-15 \\
(20,30 \%)\end{array}$ & $\begin{array}{l}16-20 \\
(9,15 \%)\end{array}$ & $\begin{array}{l}\text { More than } 20 \\
\text {-- }\end{array}$ & \\
\hline $\begin{array}{l}\text { Time for studying English } \\
\text { outside classroom per week }\end{array}$ & $\begin{array}{l}1-3 \text { hours } \\
(8,12 \%)\end{array}$ & $\begin{array}{l}4-10 \text { hours } \\
(35,53 \%)\end{array}$ & $\begin{array}{l}11-15 \text { hours } \\
(15,23 \%)\end{array}$ & $\begin{array}{l}16-20 \text { hours } \\
(8,12 \%)\end{array}$ & More than 20 \\
\hline
\end{tabular}

Table 2. Distribution of the Scores Obtained by the Participants on COLTAS

\begin{tabular}{|c|c|c|c|c|c|}
\hline Participants & $\begin{array}{l}180-144 \\
\text { Very favorable } \\
\text { attitude }\end{array}$ & $\begin{array}{l}143-109 \\
\text { Favorable attitude } \\
\text { with } \\
\text { some reservations }\end{array}$ & $\begin{array}{l}108 \\
\text { Uncertain }\end{array}$ & $\begin{array}{l}107-73 \\
\text { Unfavorable attitude } \\
\text { with } \\
\text { some reservations }\end{array}$ & $\begin{array}{l}72-36 \\
\text { Very unfavorable } \\
\text { attitude }\end{array}$ \\
\hline \multicolumn{6}{|l|}{ Female } \\
\hline Number of Participants & $9(13 \%)$ & $27(41 \%)$ & $4(6 \%)$ & $1(2 \%)$ & -- \\
\hline \multicolumn{6}{|l|}{ Male } \\
\hline Number of Participants & $7(11 \%)$ & $14(21 \%)$ & $2(3 \%)$ & $2(3 \%)$ & -- \\
\hline
\end{tabular}


Table 3. Participants' attitude toward four domains of CLT

\begin{tabular}{|c|c|c|c|}
\hline Domain & Item & $\mathrm{M}$ & $\mathrm{SD}$ \\
\hline Teacher/Student Role & & . & . \\
\hline Language classes should be student-centered, not teacher centered. & 1 & 4.21 & 0.98 \\
\hline $\begin{array}{l}\text { Teachers should make an analysis of student needs in order to design suitable } \\
\text { tasks and activities in English. }\end{array}$ & 18 & 4.09 & 1.01 \\
\hline $\begin{array}{l}\text { Helping students develop the use of context-appropriate language should be } \\
\text { the primary goal of language teaching. }\end{array}$ & 27 & 3.98 & 1.03 \\
\hline $\begin{array}{l}\text { Most of the interaction in the class should be from students to students, not } \\
\text { from teachers to students. }\end{array}$ & 31 & 3.76 & 1.09 \\
\hline \multicolumn{4}{|l|}{ Pair/group Work } \\
\hline Pair work develops oral conversational skills in English. & 6 & 4.01 & 1.05 \\
\hline Group work creates a motivating environment to use English. & 7 & 3.79 & 1.04 \\
\hline $\begin{array}{l}\text { Teacher feedback should be mainly focused on the content of the activity not } \\
\text { on the form of language. }\end{array}$ & 10 & 3.87 & 1.06 \\
\hline $\begin{array}{l}\text { Pair work provides a greater amount of student involvement than a } \\
\text { teacher-led activity. }\end{array}$ & 15 & 4.02 & 0.99 \\
\hline $\begin{array}{l}\text { Group work helps those students who are not willing to speak in front of a } \\
\text { full class. }\end{array}$ & 16 & 3.95 & 1.01 \\
\hline Group work increases the quantity of oral/aural language practice. & 34 & 3.96 & 1.02 \\
\hline \multicolumn{4}{|l|}{ Grammar } \\
\hline To develop communicative skills, explicit grammar teaching is not necessary. & 13 & 3.78 & 1.04 \\
\hline $\begin{array}{l}\text { Emphasis should be on language use rather than language rules while } \\
\text { teaching English in the class. }\end{array}$ & 14 & 3.99 & 1.05 \\
\hline $\begin{array}{l}\text { Meaning focused activities are more effective to develop communicative } \\
\text { ability than form-focused activities. }\end{array}$ & 22 & 3.67 & 1.02 \\
\hline $\begin{array}{l}\text { Grammar teaching may be included in a lesson as a means of } \\
\text { communication, not as the main goal of teaching. }\end{array}$ & 33 & 3.98 & 1.12 \\
\hline \multicolumn{4}{|l|}{ Peer/Teacher Correction } \\
\hline $\begin{array}{l}\text { Teacher correction should be avoided when it interrupts the flow of } \\
\text { communication via student interaction. }\end{array}$ & 3 & 3.31 & 1.02 \\
\hline Teachers should allow opportunity for student-student correction in English. & 8 & 3.27 & 1.15 \\
\hline $\begin{array}{l}\text { Teacher feedback should be mainly focused on the appropriateness of the } \\
\text { student responses rather than the linguistic accuracy of the forms. }\end{array}$ & 20 & 3.54 & 1.09 \\
\hline $\begin{array}{l}\text { Teacher correction should be provided only when it is required for effective } \\
\text { communication. }\end{array}$ & 25 & 3.19 & 1.17 \\
\hline
\end{tabular}


Table 4. Distribution of the Scores Obtained by the Participants with FLCAS

\begin{tabular}{|c|c|c|c|c|c|}
\hline Participants & $165-133$ & $132-100$ & $99-67$ & $66-34$ & 33 \\
\hline \multicolumn{6}{|l|}{ Female } \\
\hline Number of Participants & $7(11 \%)$ & $23(35 \%)$ & $4(6 \%)$ & -- & -- \\
\hline \multicolumn{6}{|l|}{ Male } \\
\hline Number of Participants & $4(6 \%)$ & $25(38 \%)$ & $3(4 \%)$ & -- & -- \\
\hline
\end{tabular}

Table 5. Participants' Language Learning Strategy

\begin{tabular}{|c|c|c|}
\hline Statements (abbreviated) & $\begin{array}{c}\text { Group } 1 \\
\mathrm{M}\end{array}$ & $\begin{array}{c}\text { Group } 2 \\
\mathrm{M}\end{array}$ \\
\hline 1: reading aloud & 3.12 & 2.79 \\
\hline 2: consciously learning new vocabulary & 3.76 & 3.0 \\
\hline 3: making a sentence when learning a new word & 3.55 & 2.98 \\
\hline 4: using an English-English dictionary & 2.99 & 2.23 \\
\hline 5: trying to think in English & 2.99 & 2.88 \\
\hline 6: skimming & 3.28 & 3.14 \\
\hline 7: predicting or guessing & 3.12 & 2.77 \\
\hline 8: learning from mistakes & 3.89 & 3.90 \\
\hline 9: using synonym or antonym & 3.13 & 2.96 \\
\hline 10: setting learning goals & 3.18 & 2.69 \\
\hline 11: learning from the teacher & 4.0 & 4.16 \\
\hline 12: reading newspaper in English & 2.67 & 2.35 \\
\hline 13: watching TV in English & 4.11 & 4.09 \\
\hline 14: reading English magazines for pleasure & 3.85 & 3.06 \\
\hline 15: listening to the radio in English & 3.46 & 3.23 \\
\hline 16: discussing with classmates & 4.18 & 3.75 \\
\hline 17: making friends with native speakers & 2.46 & 1.59 \\
\hline 18: Self-assessment & 2.68 & 1.99 \\
\hline
\end{tabular}

